\title{
Nationalism with a Human Face? European Human Rights Judgments and the Reinvention of Nationalist Politics
}

\author{
Kristin Henrard ${ }^{1}$ and Peter Vermeersch ${ }^{2 *}$ \\ ${ }^{1}$ Erasmus School of Law, Erasmus University Rotterdam, Rotterdam, The Netherlands \\ ${ }^{2}$ LINES, KU Leuven, Leuven, Belgium \\ *Corresponding author. Email: peter.vermeersch@kuleuven.be
}

\begin{abstract}
In this article, we show how judgments of the European Court of Human Rights (ECtHR) have provided nationalists with an unexpected opportunity to promote a nationalist discourse that is seemingly in line with human rights while fundamentally at odds with the countermajoritarian core of human rights. We start our analysis with two judgments in which the Court accepted the arguments of liberal democratic states to infringe fundamental rights of persons belonging to (immigrant) Muslim minorities in the name of "requirements of living together" or "social integration": SAS v France (2014) and Osmanoglu and Kocabas v Switzerland (2017). Strikingly, the justifications by the states for these infringements point to concerns about perceived threats to national identity and culture. We show how nationalist politicians in countries with minority populations, including those in East Central Europe, have used justifications in terms of national self-protection, tacitly or explicitly, to pursue old anti-human rights agendas. The case law discussed here enabled them to present these justifications as ECtHR proof, notwithstanding the underlying nationalism.
\end{abstract}

Keywords: nationalism, European Court of Human Rights, minorities, majoritarianism 


\section{Introduction: The European Court of Human Rights, Minorities' Separate Identity, and}

the Margin of Appreciation Doctrine

The European Court of Human Rights (ECtHR) is undeniably one of the most widely respected international human rights courts, its jurisprudence often being a source of inspiration for other courts, both national and international. ${ }^{1}$ It has come a long way since its early jurisprudence in which the lack of a minority-specific provision in the European Convention on Human Rights (ECHR) translated into a restrictive interpretation of rights in response to claims put forward by ethnic, religious, and linguistic minorities (Henrard 2009, 314, 318-328, 343-345). Indeed, the Court's jurisprudence now opens more generously toward real, substantive equality (going beyond mere formal equality) ${ }^{2}$ and enables, by way of principle, the protection of minorities' separate identity. It has recognized that, in line with the counter-majoritarian core of fundamental rights (Augenstein 2013, 469, 471), liberal democracies need to protect minorities' identity and lifestyle. Specifically, since its seminal Chapman v The United Kingdom (2001) judgment, the Court has outlined this obligation in article 8 of the ECHR — which provides a right to respect for one's private life, family life, and home - as encompassing a right to be respected in a separate way of life, with the implication that minorities' special needs should be taken into account when making and applying laws (Article 8 ECHR 2001, para. 96). Admittedly, it has been highlighted repeatedly that the Court's jurisprudence (still) paints a rather mixed picture, particularly because it tends to grant states a wide margin of appreciation in relation to (controversial) requests to accommodate the minority identity (Henrard 2016, 2017, 2019; Bretscher 2017; Peleg 2018). ${ }^{3}$

In view of the following critical analysis of particular judgments of the Court, it is important to provide some background on the margin of appreciation, which is a jurisprudential 
doctrine developed by the Court, ${ }^{4}$ following which states are granted a certain discretion in deciding whether a limitation to a fundamental right is proportionate (or not) to the legitimate aim invoked (Yourow 1996; Christoffersen 2009). Most fundamental rights are not absolute, and states are allowed to limit the enjoyment of these rights as long as they respect particular requirements as spelled out in the respective limitation clauses. The Court's overarching requirement is that the limitation should be proportionate to the particular aim that the state invokes from an exhaustive list of legitimate aims (Schokkenbroek 2006). As can be drawn from the above explanation, the margin of appreciation is particularly visible in the Court's reasoning in relation to the proportionality requirement.

The Court has based the margin of appreciation doctrine on the subsidiary protection that it is supposed to provide in relation to the primary responsibility of the contracting states to secure the fundamental rights enshrined in the ECHR (see also "Additional Protocol to the ECHR," no. 15). While it is true that human rights do not require a uniform application, and states can choose different levels of protection above the threshold, the margin of appreciation concerns the delimitation of the minimum threshold that needs to be respected. As such, several interrelated criticisms can and have been formulated in relation to the doctrine. Essentially, the idea of the margin of appreciation is difficult to reconcile with the overarching interpretation principle of fundamental rights, following which legitimate limitations should be interpreted narrowly. The latter arguably points to a rather high baseline level of scrutiny and thus, with the emphasis on supervision by the Court (Itzocovich 2013), is in line with the commitment of the contracting states to "abide by the final judgments of the Court in any case in which they are parties" (ECHR, article 46, para. 1). Granting states a margin of appreciation, however, puts the supervision back in the hands of the states, thus enabling them to protect their national constitutional identity and related sensitivities at the expense of 
the effective protection of fundamental rights (Krunke 2016). While the Court likes to emphasize that local authorities are better placed to assess local particularities when making the proportionality assessment, one can also argue that sensitive, controversial situations are perhaps better supervised at a more remote level where there is more distance from the local pressures and the illusion of the day (Henrard 2019).

Importantly, the margin of appreciation does not have one particular size; the Court determines its width case by case, going from very narrow to very broad. When the margin of appreciation for states is narrow, the Court scrutinizes strictly and provides guidance to the contracting states. However, the above-mentioned risk of jeopardizing the effective protection of fundamental rights is particularly high when the margin of appreciation left to states is broad because this implies a very light level of scrutiny by the Court. A light scrutiny tends to translate into a weak protection of the right concerned because the Court de facto steps back and tends to leave it to the states to deal with the matter (Christoffersen 2009; Kumm 2009; Henrard 2012).

As the determination of the width of the margin of appreciation is of crucial importance for the level of scrutiny adopted by the Court, and thus strongly influences the level of protection provided, one would expect this determination to be well reasoned and follow transparent criteria that are used consistently. Unfortunately, the Court has so far not yet expressed a coherent theory about the margin of appreciation doctrine, the factors relevant to the determination of its width, or how the relative weight of these factors (when pulled in different directions) should be determined (Greer 2006). It is important to note that the margin of appreciation is not an unarguable fact that objectively imposes itself on the Court; rather, the Court decides what factors should be accorded most weight, thus determining its 
width. In this respect, the Court can be seen to "shape" the margin of appreciation, so as to accommodate its legitimacy concerns toward the contracting states (Henrard 2019): identifying a broad margin of appreciation enables the Court to step back when it expects a high degree of contestation by contracting states. Indeed, the Court may have the power to pronounce legally binding judgments, it is a supranational court that ultimately depends on the contracting states to comply with its judgments. ${ }^{5}$ Granting a broad margin of appreciation to contracting states enables the Court to not pronounce a judgment (in which it establishes a violation), possibly triggering widespread and sustained contestation among the states. In this respect, the margin of appreciation amounts to an important tool to manage the balance of power between the Court and the contracting states (Follesdal, Peters, and Ulfstein 2013; Henrard 2019).

Regarding the tendency of the Court to grant states a wide margin of appreciation in relation to claims to accommodate the minority identity: it has been demonstrated that over time, the Court has narrowed the states' margin of appreciation in relation to particular claims for accommodation by religious minorities (Henrard 2016). Nevertheless, a narrow margin of appreciation is only granted for concrete matters about which the Court perceives sufficient European consensus, such as the protection of conscientious objectors. Conversely, the Court maintains jurisprudence on the broad margin of appreciation for religious matters about which it does not perceive a significant European consensus, such as religious accommodation in the workplace and the regulation of religious garments, ${ }^{6}$ particularly in educational and public service settings (Ebrahimian v France 2016).

The focus here is on several recent cases that revolve around the place of, or for, ethnic and religious minorities in societies that point to a particularly worrying development in the 
Court's jurisprudence: a turning away from the counter-majoritarian core of human rights. This turn to majoritarianism is of concern because it goes against the most fundamental, grounding principle of the human rights paradigm and further heightens and extrapolates the above-identified risks that the margin of appreciation jeopardizes the effective protection of fundamental rights. Ironically, this turn toward majoritarianism comes at a time of renewed nationalism and xenophobia when extra vigilance, not abstinence, by international courts is needed.

The cases focused on here concern claims by religious minorities with migrant backgrounds to be respected in their own religiously inspired way of life and justifications by governments for restrictions in the name of respect for the minimum requirements of life in society, living together, and social integration. ${ }^{7}$ Strikingly, the Court accepted these justifications (and thus the limitations), notwithstanding the pointers to underlying concerns about perceived threats to national identity and culture by the divergent way of life of minorities and thus pointers to the government's (veiled) nationalist agendas.

We argue that the Court's reasoning in these cases downsizes human rights to fit governments' perspectives on what is needed to obtain an integrated society while safeguarding national identity, thus enabling nationalist governments to dress up their nationalist agendas with a human face. In the process, the Court drifts away from the countermajoritarian core of human rights protection and seems to bypass long-standing principles favorable to minority protection. Ultimately, one of the most prominent human rights courts thus de facto allows (and risks fuelling) nationalist politics while sacrificing the fundamental rights of religious minorities with migrant backgrounds. 
To substantiate our argument, we first turn to an analysis of the two most prominent of these recent cases, namely SAS v France (2014) and Osmanoglu and Kocabas v Switzerland (2017), and expose how the Court de facto rubber stamps nationalist, protectionist agendas at the expense of fundamental rights of religious minorities with migrant backgrounds. Second, we discuss how court decisions interact in complex ways with the sociopolitical context (i.e., when decisions pertain to questions of national identity with the politics of majoritarianism

and cultural essentialization). Third, we reflect on the more general risk this type of reasoning by an international human rights court poses for the position of ethnic and religious minorities in European societies (and beyond) by noting the denial of the countermajoritarian core of the human rights paradigm and tracing how "nationalism with a human face" is exploited by certain governments. We conclude with some suggestions on how to counter the risk that human rights are captured by anti-human rights politics.

\section{Questionable Reasoning in Terms of "Living Together" and "Social Integration" in Recent Decisions of the European Court of Human Rights}

In $S A S$ v France (2014), a French Muslim woman who regularly wears the full-face veil, or burqa, in public claimed that French law prohibiting and criminalizing the concealment of one's face in public spaces violated her right to manifest her religious beliefs and constituted indirect discrimination on grounds of religion (which disproportionately affects women who for religious reasons want to wear a garment that covers the face) (para. 74). In this respect, it is important to go beyond the fact that the law is facially neutral and take into account the broader national context of anti-Muslim sentiment. It is particularly noteworthy that the parliamentary negotiations of the bill had demonstrated that these were indeed tainted by Islamophobic remarks (para. 149), ${ }^{8}$ which added credence to the argument that the bill was targeted against Muslim women wearing the burqa. ${ }^{9}$ 
The Court accepted that the law amounted to a limitation of the right to manifest one's religion and that it did indeed particularly affect Muslim women who for religious reasons wish to wear the burqa in public (paras. 109, 161). Nevertheless, the Court accepted that this limitation (and disproportionate impact) was justified, as it furthered a legitimate aim and was proportionate to that aim (paras. 157-159, 161). As was highlighted above, states can limit most fundamental rights, ${ }^{10}$ but because of the intrinsic link between human dignity and human rights, it is essential that states comply with the requirements for such limitations and that these limitations are duly reviewed (see Itzcovich 2013). What deserves special attention here as being problematic in terms of the Court providing a human rights platform that can be abused by nationalist governments to further their (assimilationist) agenda is the way in which it interpreted and applied the standard criteria of particular legitimate aims and proportionality. There are two elements in the Court's reasoning that must be highlighted here.

First, the Court accepted the French government's arguments that "the minimum requirements of life within French society" and "living together" amount to one of the legitimate aims that are exhaustively identified in the relevant ECHR articles, namely "the rights of others" (SAS v France 2014, paras. 121-122). However, what are these minimum requirements of life within French society? A closer look at the government's reasoning shows that it put forward a particular understanding of "living together," one that supposedly reflects the mores of French society. According to the French government, concealing one's face in public spaces inhibits the possibility of interpersonal relationships, which "by virtue of an established consensus, forms an indispensable element of community life within the [French] society" (SAS v France 2014, paras. 82, 122). Wearing a veil would thus be 
contrary to the (French) ideal of fraternity and a manifest refusal of the principle of living together (para. 82). In other words, the government presented the wearing of the burqa as a threat to French national identity, which must be strongly rejected. ${ }^{11}$ The applicant remarked that the government's concept of "minimum requirements of living together" "fails to take into account the cultural practices of minorities which did not necessarily share this philosophy” (para. 77).

Relatedly and more importantly, who are the "others" the protection of whose rights would legitimate a limitation of the rights of the claimant (and other similarly placed women)? The French government's argumentation opposes the rights of the national majority - as the rights of others - to the rights of the minority, while the former are allowed to trump the latter. Unfortunately, "the Court is . . able to accept that the barrier raised against others by a veil concealing the face is perceived by the respondent state as breaching the right of others to live in a space of socialisation which makes living together easier" (SAS v France 2014, para. 122). However, in accepting this argumentation, the Court's reasoning is fundamentally at odds with the counter-majoritarian core of human rights. Indeed, the historical development of (thinking about) fundamental rights reveals that these rights were initially conceptualized as rights for persons belonging to (religious) minorities and as persons who are in (special) need of protection against the power of the state (Rosting 1923, 642; De Azcarte 1945 [with special reference to the protracted period of religious wars in Europe between 1524 and 1648]; Liebich 2008). While these rights were later extended to everyone, this has gone hand in hand with an understanding, also by the ECtHR that "the views of the majority must not always prevail, rather ... ensures fair treatment of people from minorities and avoids any abuse of a dominant position" ( SAS v France 2014, para. 128) (see also Young, James and 
Webster v The United Kingdom 1981, para. 63; Chassagnou and Others v France 1999, para. 112; Osmanoglu and Kocabas v Switzerland 2017, para. 84).

Second, this majoritarian drive is not only visible in relation to the identification of the legitimate aim but also hardened by the total disregard of the applicant minorities' divergent views on integration in the Court's proportionality review. Indeed, even though the concept of integration is not explicitly used by applicant, government, or Court, the judgment is arguably replete with integration language, particularly the references to living together and requirements of life within French society. ${ }^{12}$

When reviewing the legitimate aim requirement, the Court had recognized that the inherent flexibility of the notion of living together and the related risk of abuse required a careful examination of the necessity of the measure concerned (Young, James and Webster $\mathrm{v}$ The United Kingdom 1981, para. 63; Chassagnou and Others v France 1999, para. 112; SAS v France 2014, paras. 122, 128; Osmanoglu and Kocabas v Switzerland 2017, para. 84). The Court expressed its concern in this respect about the information it had received from thirdparty interveners that certain Islamophobic remarks had been made during the debate preceding the adoption of the law concerned. The Court also acknowledged that when a state in this context adopts a law of this kind it risks contributing to the consolidation of the stereotypes that affect certain categories of the population and encouraging the expression of intolerance when it has a duty, on the contrary, "to promote tolerance" (SAS v France 2014, para. 149). However, these hints at the need for heightened scrutiny seem (conveniently?) to have been forgotten by the time the Court proceeded to the proportionality assessment, which tends to play a crucial and often decisive role in the Court's review. 
In $S A S v$ France (2014), the Court framed the matter in such a way that it appeared appropriate to grant France a broad margin of appreciation, resulting in minimal scrutiny. First, it qualified "the question whether or not it should be permitted to wear the full-face veil in public" as a "choice of society" (para. 154). This then fit the "general policy choices" category, which the Court traditionally responds to with a grant of a broad margin of appreciation to the state. The Court added a convoluted and unconvincing argument about the lack of European consensus on the matter, which would confirm a broad margin for the state. The Court began by acknowledging that France was in a minority position with a law that resulted in a complete ban of the burqa (para. 156). This would seem to point to a European consensus against a complete ban and thus a narrow margin of appreciation. However, the Court then pointed out that there were ongoing discussions (on the regulation of the burqa in public spaces), which would imply that there was no European consensus on the matter (para. 156).

Clearly, the Court chooses to grant a state a broad margin of appreciation in cases revolving around intricate questions of (perceived threats to) national identity. ${ }^{13}$ This conscious choice is informed by the Court's preference to step back and forego its supervisory role when faced with a sensitive matter out of concern that it might get embroiled in a legitimacy struggle with the contracting states. ${ }^{14}$ While it may be politically wise and strategic to avoid these struggles, the Court ends up validating state arguments notwithstanding their nationalist inspiration.

In Osmanoglu and Kocabas $v$ Switzerland (2017), particular expressions of religious convictions were not criminalized, but Muslim parents were required to pay a substantial fine for not letting their girls participate in mixed swimming classes because this was contrary to 
their religious convictions (para. 33). The Court acknowledged that the impossibility to obtain an exemption from these classes amounted to an interference with the parents' right to have their religious beliefs respected in the education of their children (para. 42). However, the Court also concluded that the fundamental rights concerned were not violated because the interference was justified as being proportionate to the legitimate aim invoked (para. 105). Thus, this case also allows for critical remarks to be made about the aim that the Court accepted as being legitimate in terms of the ECHR and about the proportionality assessment in the sense that the Court (de facto) enables governments to pursue a nationalist agenda (and impose the national majority way of life) under a veil of human rights compliance.

In other words, in Osmanoglu and Kocabas v Switzerland (2017), the Court accepted the Swiss government's argument that not granting the exemption and obliging the Muslim girls to participate in mixed swimming classes furthered the legitimate aim of optimizing the social integration of children from different cultures and religions and protecting them against every phenomenon of social exclusion (para. 64). Admittedly, there is no mention of Islamophobic remarks in relation to either the legislative framework or its application. Nevertheless, the Swiss Federal Tribunal that heard this case underscored that the aim of social integration, understood as compliance with the prevailing social conditions in Switzerland, would be particularly relevant for the Muslim minority as it has grown significantly in recent years (Bundesgericht 2008). While this may not qualify as Islamophobia, it does single out the Muslim minority as being the object of special concern and, potentially, threatening to national identity (by outnumbering the national community).

Strikingly, this aim of "optimising the social integration of foreign children from different cultures and religions" is subsumed under the legitimate aim of "rights of others" 
(Osmanoglu and Kocabas v Switzerland 2017, para. 64). The government's arguments in this case, as in SAS v France (2014), are mostly concerned with obtaining an integrated society according to the majority's concept of what is required to obtain an integrated society. In the process, the government opposed the majority's concerns and rights to the minority's fundamental rights and allowed the former to trump the latter. The acceptance of this argument by the Court amounts to another most unfortunate manifestation of majoritarianism, which ignores the counter-majoritarian core of human rights. Relatedly, limiting the rights of parents in order to protect their children against social exclusion gets dangerously close to arguing that when one adopts a minority way of life, it is bound to lead to social exclusion. When the Court accepts this line of reasoning, it allows a government to send the message that if one wants to be socially integrated and have a good life, one must abandon (or at least minimize) one's minority way of life so that it is acceptable to the national majority. ${ }^{15}$

In relation to the legitimate aim requirement and in the Court's proportionality assessment, the Court's reasoning carries the risk of being abused by nationalist governments that seek to present their assimilationist policies as human rights proof, notwithstanding the inherent tensions with the counter-majoritarian core of human rights. The Court started its proportionality review with granting Switzerland a broad margin of appreciation as it concerned the relationship between state and religion and about which no European consensus was detected (Osmanoglu and Kocabas v Switzerland 2017, para. 87). The Court then stipulated that this margin would be especially considerable in relation to public education (paras. 92, 95). The Court followed the government's contention about the central importance of school to the process of social integration and that "the interests of children in a complete schooling allowing a successful integration according to local customs and habits prevails over the wish of parents to have their daughters exempted from mixed-sex 
swimming classes" (para. 97). The Court thus seems to have accepted that national customs and habits and the government's desire to impose these on students with minority backgrounds outweigh (parents') fundamental rights.

In this case, the Court hardened the majoritarian drive of its reasoning (visible in relation to the legitimate aim) by its blunt dismissal of the parents' divergent views on integration. The parents agreed with the importance of integration in Swiss society but argued that the family was well integrated, pointing to their knowledge of the language, the fact that they all have studied and still study, and work in Swiss society while respecting the constitutional and democratic principles of the state and its local social customs (Osmanoglu and Kocabas v Switzerland 2017, paras. 58, 60). Accordingly, the parents contested, the integration of their children would depend on their participation in mixed swimming classes.

In Osmanoglu and Kocabas v Switzerland (2017), the Court rubber stamped the Swiss government's nationalist policies by allowing Switzerland to impose its national ways of life as superior to those of migrant minorities. The Court thus seemingly confirmed the government's message that there is room for expressions of a separate religious identity only in so far as the national majority allows them.

Overall, both $S A S v$ France (2014) and Osmanoglu and Kocabas $v$ Switzerland (2017) were a sign of their times: they originated in countries (as in many other European states) in a period when there were several vehement discussions about Islam and the Muslim presence in these societies and the related concerns about what this implies for the national society.

\section{Nationalist Uses of Court Decisions: majoritarianism and cultural essentialization}


As is clear from the discussion above, we argue that the analysis of Court decisions needs to be attentive to the sociopolitical implications of such decisions, especially when they pertain to issues of national identity. However, this argument, we realize, may require some additional explaining. The sociopolitical processes that relate to national identity formation happen far from the place where Court decisions are made. One could also claim that the Court itself does not need not to be aware of any socio-political implications or public debates in the national arenas - the human rights principles that underpin its functioning are of a more universal nature (or at least pertain to the level of supranational agreements). Yet there is an important connection between the Court and the national state that becomes clear when we consider the ways in which supranational decisions are translated into national policies. Such translation processes inevitably involve politics at the state level. It is still the decision of separate states to address issues relating to the position of a minority group that lives in more than one country. This fact may create a predicament for the members of transnational minorities, such as European Muslim populations, when they claim their rights through institutions above the level of the state. As Edmunds $(2012,1196)$ argues, "While European Muslims are increasingly using human rights as a vehicle for gaining religious rights, they have been ineffective because case history to date has delegated responsibility for decision-making to the national governments." If indeed such national governments are still the main decision makers for providing freedom and implementing human rights protections, it becomes necessary to examine the sociopolitical contexts in which national governments make and implement such decisions.

While the Court may work on the assumption of the existence of a Europe-wide form of citizenship, national governments see their decisions as relevant mostly (and perhaps uniquely) toward their own citizens. We should therefore not assume that the mere existence 
of Europe-wide supranational (judicial) institutions will lead to the waning of national frameworks or the decreasing importance of national identity. To the contrary, in the current European context, as Wodak and Boukala $(2015,87)$ argue, "It becomes apparent that debates about European identities - especially since the financial crisis of 2008 - have increasingly been accompanied by debates about both more traditional racialised cultural concerns and more recently, about economic security, leading to new distinctions between 'Us', the 'real Europeans', and 'Them', the 'Others'." This means that any decision on the supranational level that pertains to issues of cultural, religious, and community identity will almost certainly be interpreted and framed as a decision on nationhood. Therefore, the relationship between supranational legal decisions and the national sociolegal background should be part of the analysis.

What are the conceptual frameworks that we can use to understand the relationship between nationalizing sociopolitical contexts and legal decisions of the Court? We argue that several ongoing processes can be distinguished. The first is a rhetorical capture by those politicians who engage in what Brubaker $(2017,357,365)$ terms "majoritarianism." These parties and politicians abuse the line of reasoning presented by the Court to frame their old nationalist agenda in language that seemingly conforms to the legislative intent of the Court. In the context of various populist-nationalist political discourses that have recently gained visibility and strength in several places across Europe, human rights have thus acquired a modified meaning: they are framed as needed in support of the so-called majority, a group whose interests are allegedly undermined by cultural minorities. Such political discourses display a remarkable ability to create a reversal, a distorted mirror image almost, of the reasoning that originally motivated human rights legislation. They "reject discourses and practices of multiculturalism, diversity, or minority rights, seeing these as disadvantaging or symbolically 
devaluing those in the mainstream" (Brubaker 2017, 365). But they package that rejection in terms of cultural protection of those under threat. Populist nationalism, in short, relies on narratives that foreground the rights of a culturally defined majoritarian community whose allegedly neutral values and normal ways of doing things are perceived as being under threat by a cultural minority (often seemingly in secret collaboration with a supranational elite).

As products of legal reasoning, the judgments of the Court are being made within the confines of the judicial procedure — and they may be devoid of political opinion within these confines - but they acquire new meaning when they arrive in a political context that is increasingly attuned to and dominated by such majoritarianism. These judgments may be especially vulnerable to discursive capture when the legal reasoning on which they rest evokes the language of community (by, for example, relying on vague and contestable ideas on requirements of living together or social integration). Such invocations will, in the current context of rising nationalism, often be interpreted in ethnonationalist terms.

The second process can be called the essentialization of culture. This is a problem that proponents of multiculturalism have traditionally grappled with in their arguments in support of cultural recognition and minority protection. Activists who have argued for special protection measures for vulnerable cultural groups have often based their demands, even if only tacitly, on a discourse of cultural essence: they assume that cultural groups have fixed and unchangeable properties and therefore need protection for practices and values associated with these properties. The effect can be a solidification of minority identity and even a reduction of opportunities for diversity within minority communities. The phenomenon has been described by Appiah (2010) as the ossification of identities, or the Medusa Syndrome: "The politics of recognition, if pursued with excessive zeal, can seem to require that one's 
skin color, one's sexual body, should be politically acknowledged in ways that make it hard for those who want to treat their skin and their sexual body as personal dimensions of the self' (Appiah 2010, 110).

Diverse policy ideas might spring from any culturally sensitive and community-oriented political approach - an approach based on the idea of cultural recognition - and not all of them are necessarily in conflict with the human rights agenda. Whether these policies are in fact in line with larger human rights ideals depends on how cultural communities, and the hierarchies between them, are rhetorically constructed, politically framed, and practically experienced.

Populist nationalist discourse in several European countries, however, now often uses the language of cultural essence (and therefore the language of cultural recognition) not to defend protection measures for vulnerable minorities but to argue against entitlements for minority groups or even encourage discriminatory practices. In this framing, minorities are understood not as citizens in need of protection because of their cultural difference from the mainstream but as cultural others, who are unable to adapt to requirements for social integration. They may even be framed as those who threaten the cultural rights of the majority. Such politics of deliberate essentialization is especially at play in cases where the cultural practices associated with (immigrant) Muslim minorities are foregrounded. Unfortunately, the legal reasoning of the Court as problematized above can all too easily be abused by populist nationalist politicians to construct and promote an image of Muslims as antithetical to national majority culture and thereby deepen cultural rifts in society. 


\section{What Does "Nationalism with a Human Face" Mean for the Position of (Ethnic and Religious) Minorities in European Societies?}

Both judgements discussed here signal unfortunate retreats in the Court's jurisprudence in relation to the fundamental rights of persons belonging to religious minorities with migrant backgrounds to the extent that the Court's reasoning even implies a reversal of the human rights logic. Following a more overarching human rights analysis, highlighting the broader implications of the Court's reasoning in the judgments concerned, we point to the risk that these Court decisions are captured by anti-human rights politics, embodying majoritarianism and cultural essentialization.

The Court has several steady lines of jurisprudence with a principled protective stance toward the fundamental rights of minorities. A prominent and long-established line of jurisprudence underscores that "pluralism, tolerance and broadmindedness are hallmarks of a 'democratic society', [which] implies that democracy does not simply mean that the views of a majority must always prevail: a balance must be achieved which ensures the fair and proper treatment of minorities and avoids any abuse of a dominant position" (Young, James and Webster $\mathrm{v}$ The United Kingdom 1981, paras. 23, 49, 63; Gorzelik v Poland 2004, para. 90). The Court thus identifies a state duty to protect minorities against undue majority pressure. It developed this line of thinking further in its landmark judgment in Chapman $v$ The United Kingdom (2001), where it identified a state duty to take minorities' special characteristics, way of life, and related special needs into account in the regulatory framework and in the application of these norms in concrete cases. Similarly, and particularly relevant for religious minorities in the sphere of education, the Court had, since Folgero and Others $v$ Norway (2007), adopted a strict interpretation of a state's duty (article 2, protocol 1) to respect the religious convictions of parents in relation to all aspects of public education to the extent that a particular religion 
could not have a dominant position in the public curriculum (Folgero and Others v Norway 2007, paras. 90-93, 95, 101, 102; Hasan and Eylem Zengin v Turkey 2007, paras. 63, 64).

In the two cases analyzed here (SAS v France and Osmanoglu and Kocabas $v$ Switzerland), the ECtHR accepted far-reaching limitations to the rights of religious minorities with migrant backgrounds in the name of the governments' understanding of what is needed for social integration or the requirements of living together. The majoritarian reasoning adopted by the Court entirely bypassed the principles espoused in these steady lines of jurisprudence to the extent that it reversed the entire human rights logic. Indeed, instead of starting from the right to respect the separate minority identity and way of life, which can be subjected to circumscribed limitations, the Court seemed to follow the governments' underlying argument that religious minorities with migrant backgrounds are entitled to maintain and express their separate identity only in so far as the majority accepts it.

Specifically, the Court appeared willing to sacrifice minorities' fundamental rights in order to accommodate the governments' concerns about (and policies and practices to counter) perceived threats to national identity, de facto enabling them to impose the national majority way of life. The Court in SAS v France (2014) even accepted that states threaten these religious immigrant minorities with criminal sanctions and thus, in the name of living together, actually exclude these minorities from society. Similarly, the Court's argument in Osmanoglu and Kocabas $v$ Switzerland (2017) that it is legitimate to limit the rights of parents with migrant backgrounds to have their religious convictions respected in the public education of their children in order to protect their children against social exclusion is difficult to reconcile with its steady line of jurisprudence that the state is obliged to actively 
counter discriminate between private parties as much as possible (see Karaahmed v Bulgaria 2017, para. 111; Kiraly and Dömötör v Hungary 2017, paras. 60, 61).

In the end, the Court's line of reasoning in both cases allows national identity, as defined by the national majority, to eclipse minorities' identities and fundamental rights, which is contrary to (retreating from) the Court's steady line of jurisprudence on the importance of pluralism and the protection of minorities against undue majority pressure. In this way, the Court can, unfortunately, be seen to accept, confirm, and ultimately even fuel nationalist politics. Relatedly, and as underscored by several of the third-party interveners in $S A S v$ France (2014), when the Court allows sanctioning of the manifestation of particular religious beliefs it has the potential to fuel stigmatization of and racist attitudes toward the religious minorities concerned, making these minorities even more vulnerable (paras. 99, 100). Furthermore, this jurisprudence carries the risk that anything (including issues that are not directly related to national identity questions) that makes the national majority feel uncomfortable can be banned under a veil of human rights compliance (see also Brems' blog in Strasbourg Observers, July 9, Fout! De hyperlinkverwijzing is ongeldig.2014).

We are not claiming here that there is a direct causal link between the reasoning and conclusions of the ECtHR and certain negative developments in the field of interethnic relations in several European states ${ }^{16}$ and possibly even beyond Europe. ${ }^{17}$ Rather, we argue that judicial legitimations allow certain political actors to present their position against religious diversity as well as their anti-immigrant agenda as if it is in line with human rights. That does not always happen, but there is a risk that it will happen increasingly. Such judicially sanctioned rereadings of human rights are built on principles that go against the human rights tradition, and they can occur, as we have explained, because discourses about 
court decisions interact in complex ways with the politics of majoritarianism and cultural essentialization.

The signs have been visible for quite some time. A reasoning that portrays certain human rights infringements as a necessary part of the defense of threatened liberal values has been formulated by, among others, extremist politicians not only in Western European countries, such as the Netherlands and Belgium, but also in Central and Eastern European countries, such as Hungary, Poland, and Latvia, where Islamophobia is a relatively new phenomenon.

In 2003, Hirsi Ali and Wilders argued in an op-ed that, "In order to preserve the Netherlands as a tolerant and liberal country, elementary rights and laws must be set aside when dealing with people who abuse them and who subsequently want to remove them as the foundation of our society" (cited in Bot 2012, 238). It is clear that the phrase "people who abuse them" is interpreted in cultural terms. The authors do not leave any doubt about who they have in mind; they simply continued their op-ed with a call to close all Muslim schools.

Similar arguments have been made in other countries. They may seem law-and-order arguments because they usually refer to security issues, but they are something more: on top of calling for a stricter defense of legal limits and punishment for any transgressions of those limits, these arguments actively call for a permanent state of emergency to defend liberal values from alleged cultural threats. This is the language of cultural essence and majoritarianism employed to do the job of propagating nationalism as a way to protect human rights, and it permeates the political campaigns and discourses of a range of actors across Europe, and not solely in the guise of the extreme right. 
To note one example: in March 2018 in Belgium, Bart De Wever, the leader of the largest political party of the country (the Flemish nationalist N-VA), made an argument in De Standaard newspaper that provided a version of this reasoning. While a nationwide ban on public face covering has already been in place in Belgium since 2011 (Brems, Vrielink, and Chaib 2013, 70), De Wever argued that any other piece of clothing that is symbolic of Islam must also be forbidden in the public space because Muslims constitute a threat to the neutrality of that public space. He argued that there were no such problems with the external symbols (and clothing) of Orthodox Jews because Jews "avoid conflict. . . . That's the difference. ... Muslims demand a place in the public realm, in education, with their external signs of belief. That creates tension" (our translation, De Standaard, March 19, 2018). In the view of this politician, whether or not minority rights should be granted is fully dependent on (an interpretation of) the attitude of those who are members of that minority. In other words, De Wever was promoting the idea that, in the name of avoiding social conflict, the rights of certain minority groups (in response to the cultural threat of the minority group in question) should be curtailed. This is a straightforward abuse of the human rights discourse (or particular elements of it, mostly related to the protection of individual freedoms and the public realm), and its rhetoric seems all too easily unmasked. But as is clear from political debates in various European countries, it is an argumentative trick that can have remarkable tenacity in the public debate.

To learn how problematic things can become we only have to look at the ways in which the political discourses around human rights interact with the politics of majoritarianism and cultural essentialization in those European countries where Islamophobia is a relatively new sociopolitical phenomenon. It is useful to explore such new cases because they clearly illustrate that such instances of Islamophobia are far from spontaneous responses to 
increasing Muslim migration. Other factors, such as political campaigning, electoral tactics, strategic decisions in the struggle for (social) media attention, and indeed the discursive capture by politicians of judgments of influential courts, are arguably a far more influential element here. This is highly visible when political actors (in some cases, government parties) suddenly contribute to creating a moral panic around the presence of a Muslim population that was up to that point never the focus of public attention. They frame their political proposals (and actions) as an attempt to defend their own community against outsiders and their common European values against threats from abroad.

The foremost example in East Central Europe is no doubt Hungary, under the leadership of Viktor Orbán (Fidesz). In this country, a small immigrant population (in 2015, it was estimated at less than 2 percent of the population) and an even smaller population of Muslim inhabitants (estimated at less than 0.3 percent) were in the 1990s and early 2000s never the focus of any major political campaigning. But in 2015, in response to national institutions failing to deal adequately with a sudden rise in the number of asylum claims and transit refugees, the government launched "a fierce anti-immigration campaign that also gave rise to anti-Muslim narratives" (Vidra 2017, 11). This anti-immigration narrative-which led to dubious political actions, such as establishing a razor fence at the border, erecting large-scale anti-immigrant billboards, and setting up a referendum against European Union (EU) resettlement quotas - was couched in terms of security (protection against terrorism) and framed as a necessary resistance against a misguided European civilization attempt. Ultimately, the anti-immigration narrative transformed into a more radical antidiversity narrative, tying in with a backlash against the norms on minority protection that the EU had promoted during the Eastern enlargement process (i.e., norms on minority protection in the Copenhagen criteria and references to the Framework Convention on the Protection of 
National Minorities). Orbán (2018) has argued on several occasions that he is against diversity. At the annual meeting of the Association of Cities with County Rights in February 2018, he claimed, "We do not want to be diverse and do not want to be mixed: we do not want our own colour, traditions and national culture to be mixed with those of others" (Orbán 2018). Simultaneously, however, such campaigns were presented as a defense of European (religious) culture and age-old values.

At first glance, this would appear a rather perfunctory and strangely selective endorsement of European values - an endorsement that does not mention human rights as part of the European heritage - but its effect on folk understandings of human rights is tremendous. This very reasoning is used by those Hungarian extremist politicians who have wanted to introduce local bans on Islamic symbols and thereby actively sought to delegitimize the presence of Muslims (and other religions) in the name of preserving Hungarian traditions. A similar observation can be made about the Hungarian minority rights policies and institutions that were established in recent years. The seemingly minority-friendly legislation is mostly designed to foster the connection between Hungary and the Hungarian minorities abroad. With regard to its functioning internally, Pap $(2018,90)$ characterizes it as "illiberal multiculturalism.” Under the current government, the minority protection system fails to provide adequate protection from discrimination and is accompanied by an explicit condemnation of multiculturalism. As Orbán said, "We will do everything under our power to spare Hungary from this" (cited in Pap 2018, 101).

The complexity of the Hungarian case is that Orbán's campaigns seem to defend as well as resist the idea of liberal values as an essence of Europe. As Vidra (2017) notes, Hungarian government-supported Islamophobia cannot wholeheartedly incorporate human rights values 
because these ideas are associated with the civilizing mission of the EU. So there is the tendency instead to treat Islam and Muslims "as enemies not because they are in opposition with our liberal democratic [and human rights] values, but because they have a religion/culture that is incompatible with ours" (Vidra 2017, 23). European court decisions are not part of that political discourse (at least so far) because such discourse is driven by its stance against human rights values; but the reasoning underlying this stance seems to come close to the arguments given by the Court in the cases we have discussed (particularly the Court's arguments on respect for the minimum requirements of life in society, living together, and social integration).

Another important example of such political and rhetorical complexity is seen in Poland. Recent electoral campaigns in that country indicate a return of nationalism to the center of political discussion and have rekindled an essentialized view of Polish national identity against cultural and religious "others." The Polish Law and Justice party portrays itself as the defender of Polishness against old political enemies, who are allegedly sponsored by Russia or Germany. Moreover, a new threat has been found in refugees and asylum seekers, who are defined, tacitly or openly, as non-Catholic invaders. This is obviously problematic not only for (the small number of) migrants, asylum seekers, and refugees in Poland (who often by the very fact that they are immigrants are seen as Muslim) but also for indigenous Polish Muslims (for example, the small Tatar minority, recognized as a Polish national minority), who see themselves suddenly placed outside national culture. In total, Polish Muslims make up just 0.1 percent of the entire population (35,000 to 40,000 people), but the rhetorical focus on them not only has lowered their chances for better minority protection but also has increased the level of potential conflict with other Polish citizens (Narkowicz and Pędziwiatr 2017, 288-289). 
In Latvia, we see an even more direct consequence of internationally sanctioned legal decisions on the "burqa ban." Latvia has a population of less than 2 million, which according to official estimates includes about 1000 Muslims. In 2016, Martyn-Hemphill reported in the New York Times that the Latvian government, citing a desire to protect Latvian culture and address security concerns at a time of rising migration to Europe, was "working on proposed legislation, inspired partly by similar restrictions on head coverings in France, that would ban face-covering veils from public spaces. The proposal would not ban the wearing of head scarves that do not cover the face, like hijabs, the coverings most commonly worn by Muslim women" (New York Times, April 20, 2016). Latvia's Minister of Justice Dzintars Rasnacs called it a piece of legislation to protect the values of Europe and is quoted as stating that "the law was not about the number of people covering their faces in Latvia, but had more to do with ensuring that prospective immigrants respect the norms of this small and homogeneous country. ... We do not only protect Latvian cultural-historical values, but the culturalhistorical values of Europe" (New York Times, April 20, 2016). Press reports have since followed, documenting how Latvian Muslims have increasingly become the target of verbal abuse. In 2016, Hamza Jānis Luciņš, the leader of the Islamic Cultural Centre in Latvia, noted the increasing presence of Islamophobia and hate speech on the Internet (Gurbo 2016).

As noted above, we are not claiming that these national developments are causally related to the pronouncements of the Court in SAS v France (2014) and Osmanoglu and Kocabas $v$ Switzerland (2017). But the Court's reasoning in these prominent cases not only failed to call a halt to these nationalist developments but also risked being actively abused by nationalist movements in an expanding range of European countries, both in the East and in the West. Still, we hasten to add that that we are not suggesting that the intent of these national 
lawmakers is to promote discriminatory behavior; the matter might be more complicated than that, and various political motivations may be behind any legislative initiative. But the examples do clearly highlight that such legislative initiatives might have a detrimental effect on folk interpretations of state neutrality and thereby encourage discriminatory behavior. In other words, under the pretext of state neutrality and even liberal values derived from a human rights heritage, people can begin to argue for acts of cultural value protection that explicitly disadvantage certain minority populations.

\section{Conclusions}

If court decisions and their underlying arguments increase the risk of letting human rights be captured by politics that are anti-human rights, the question we are left with is how to counter that risk. One conclusion would be to signal the importance of caution in the argumentation of court decisions pertaining to the expression of a separate identity of minorities with migrant backgrounds. It is essential that prominent human rights courts do not mimic (and rubber stamp) governments' misuse of integration arguments to disproportionately limit minorities' enjoyment of fundamental rights, particularly the freedom to manifest one's religion, thus exposing them to assimilationist pressures. The decisions are not made in a sociopolitical vacuum, and therefore the court's argumentation might increase the risk of rhetorical capture for political agendas that are not in line with the general spirit of human rights.

This ties in with the critical remarks about the Court's worrying turn (in the cases discussed here) to majoritarian reasoning, contrary to the counter-majoritarian core of human rights. In the process, the multiple problems with the margin of appreciation as a jurisprudential construct that jeopardizes the effective protection of fundamental rights are both confirmed 
and aggravated. The cases clearly demonstrate how the flaws of the margin of appreciation (in terms of conceptualization and operationalization of its width) are particularly dangerous in a political climate of renewed nationalism and xenophobia. Indeed, it is exactly in such a political climate that extra vigilance, instead of abstinence, by international courts is needed. The preceding arguments open the way toward a firm recommendation to the Court to develop a more transparent and consistent methodology for the determination of the width of the margin of appreciation while being overall reticent to grant a broad margin to the contracting states. After all, the Court should embrace its mandate and provide the necessary guidance to the contracting states on the effective protection of fundamental rights as well as, or maybe even especially, controversial topics that states perceive as intertwined with their national (constitutional) identity.

An important task also lies ahead for education on human rights across Europe. Awarenessraising activities should make people (including activists, NGOs, and politicians) more conscientious about the fundamental nature and limited possibilities to restrict human rights, thereby making the population less captive to easy populist credos and creating more realistic folk interpretations of such principles as state neutrality, liberal freedoms, and minority protection.

Financial Support. There are no funders to report for this submission.

Disclosure. The authors have nothing to disclose. 


\section{References}

Appiah, Kwame A. 2010. The Ethics of Identity. Princeton, NJ: Princeton University Press.

Augenstein, Daniel. 2013. "Normative Fault-Lines of Trans-National Human Rights

Jurisprudence: National Pride and Religious Prejudice in the European Legal Space.” Global Constitutionalism 2 (3): 469-497.

Bot, Michiel. 2012. "The Right to Offend? Contested Speech Acts and Critical Democratic Practice." Law and Literature 24 (2): 232-264.

Brems, Eva. 2014. “SAS v France as a Problematic Precedent.” Strasbourg Observers, July

9. https://strasbourgobservers.com/2014/07/09/s-a-s-v-france-as-a-problematicprecedent/Fout! De hyperlinkverwijzing is ongeldig.

Brems, Eva, Jogchum Vrielink, and Saïla Ouald Chaib. 2013. "Uncovering French and Belgian Face Covering Bans.” Journal of Law, Religion and State 2 (1): 69-99.

Bretscher, Fabienne. 2017. "Religious Freedom of Members of Old and New Minorities: A Double Comparison.” Erasmus Law Review 10 (3): 151-162.

Brubaker, Rogers. 2017. "Why Populism?” Theory and Society 46 (5): 357-385.

Bundesgericht [BGer] [Federal Supreme Court] (2008). 2C_149/2008 [Switz.], Oct. 24, 2008. 
Christoffersen, Jonas. 2009. Fair Balance: Proportionality, Subsidiarity and Primarity in the ECHR. Leiden: Brill.

De Azcarate, Pablo. 1945. League of Nations and National Minorities: An Experiment. Washington, DC: Carnegie Endowment for International Peace.

De Wever, Bart. 2018. “Zijn sommige minderheden assertiever dan andere? Het verschil tussen joden en moslims volgens De Wever.” De Standaard, March 19. http://www.standaard.be/cnt/dmf20180318_03416330.

Edmunds, June. 2012. “The Limits of Post-National Citizenship: European Muslims, Human Rights and the Hijab.” Ethnic and Racial Studies 35 (7): 1181-1199.

European Court of Human Rights. 1981. Young, James and Webster v The United Kingdom. August 13. Application Nos. 7601/76, 7806/77.

. 1999. Chassagnou and Others v France. April 29. Application Nos. 25088/94, $28331 / 95,28443 / 95$.

. 2000. Thlimmenos v Greece. April 6. Application No. 34369/97. 2001. Chapman v The United Kingdom. January 18. Application No. 27238/95. 2004. Gorzelikv Poland. February 17. Application No. 44158/98. 
- 2007. Folgero and Others v Norway. June 29. Application No. 15472/02.

. 2007. Hasan and Eylem Zengin v Turkey. October 9. Application No. 1448/04.

2014. SAS v France. July 1. Application No. 43835/11.

2016. Ebrahimian v France. February 26. Application no. 64846/11.

2017. Belkacemi and Oussar v Belgium. July 11. Application No. 37798/13.

2017. Dakir v Belgium. July 1. Application No. 4619/12.

2017. Hamidovic v Bosnia Herzegovina. December 5. Application No. 57792/15.

2017. Karaahmed v Bulgaria. February 24. Application No. 30587/13.

2017. Kiraly and Dömötör v Hungary. January 17. Application No. 10851/13.

2017. Osmanoglu and Kocabas v Switzerland. January 10. Application No.

$29086 / 12$

2018. Lachiri v Belgium. November 23. Application No. No. 3413/09. 
Europe's Human Rights Watchdog. n.d. Supervision of the Execution of Judgments. https://www.europewatchdog.info/en/structure/committee-of-ministers/supervisionexecution-judgments/.

Ferri, Marcella. 2017. "Belkacemi and Oussar v Belgium and Dakir v Belgium: The Court Again Addresses the Full-Face Veil, But It Does Not Move Away from Its Restrictive Approach." Strasbourg Observers, July 25.

https://strasbourgobservers.com/2017/07/25/belkacemi-and-oussar-v-belgium-and-dakir-vbelgium-the-court-again-addresses-the-full-face-veil-but-it-does-not-move-away-from-itsrestrictive-approach/.

Follesdal, Andreas, Birgit Peters, and Geir Ulfstein. 2013. "Introduction.” In Constituting Europe: The European Court of Human Rights in a National, European and Global Context, edited by Andreas Follesdal, Birgit Peters, and Geir Ulfstein, 1-24. Cambridge UK: Cambridge University Press.

Greer, Steven. 2006. The ECHR: Achievements, Problems and Prospects. Cambridge UK: Cambridge University Press.

Gurbo, Simona. 2016. "Latvia." In Yearbook of Muslims in Europe Online. Vol. 9, edited by Oliver Scharbrodt, Samim Akgönül, Ahmet Alibašić, Jørgen S. Nielsen, Egdūnas Račius. Leiden: Brill. https://referenceworks.brillonline.com/browse/yearbook-of-muslims-in-europeonline. 
Henrard, Kristin. 2009. “A Patchwork of 'Successful' and 'Missed' Synergies in the Jurisprudence of the ECHR." In Synergies in Minority Protection, edited by Kristin Henrard and Robert Dunbar, 314-364. Cambridge UK: Cambridge University Press.

- 2012. "A Critical Appraisal of the Margin of Appreciation Left to States Pertaining to 'Church-State Relations' under the Jurisprudence of the ECtHR.” In A Test of Faith? Religious Diversity and Accommodation in the European Workplace, edited by Marie-Claire Foblets, Katayoun Alidadi, and Jogchum Vrielink, 59-86. Farnham, UK: Ashgate.

_. 2016. "The European Court of Human Rights, Ethnic and Religious Minorities and the Two Dimensions of the Right to Equal Treatment: A Jurisprudence at Different Speeds?" Nordic Journal on Human Rights 34 (3): 157-177.

- 2017. "Case Law of the European Court on Human Rights Concerning Ethnic, Religious and Linguistic Minorities over 2014: About Differential Margins of Appreciation and the Role of the Prohibition of Discrimination." In European Yearbook of Minority Issues. Vol. 13, edited by European Centre for Minority Issues and The European Academy Bozen/Bolzano, 248-282. Leiden: Brill.

—. 2018. "The Effective Protection against Racial Discrimination and the Burden of Proof: Making up the Balance of the Court of Justice's Guidance.” In EU AntiDiscrimination Law beyond Gender, edited by Uladzislau Belavusau and Kristin Henrard, 95-117. Oxford: Hart Publishing. 
—. 2019. "How the ECtHR's Use of European Consensus Considerations Allows Legitimacy Concerns to Delimit Its Mandate.” In Building Consensus on European Consensus: Judicial Interpretation of Human Rights in Europe and Beyond, edited by Panos Kapotas and Vassilis Tsevelekos, 141-166. Cambridge UK: Cambridge University Press.

Itzcovich, Giulio. 2013. "One, None and One Hundred Thousand Margins of Appreciations: The Lautsi Case.” Human Rights Law Review 13 (2): 287-308.

Krunke, Helle. 2016. "Courts as Protectors of the People: Constitutional Identity, Popular Legitimacy and Human Rights." In Judges as Guardians of Constitutionalism and Human Rights, edited by Martin Scheinin, Helle Krunke, and Marina Aksenova. Cheltenham, UK: Edward Elgar.

Kumm, Mattias. 2009. Democracy is Not Enough: Rights, Proportionality and the Point of Judicial Review. Public Law Research Paper No. 09-10. New York: NYU School of Law.

Liebich, Andre. 2008. "Minority as Inferiority: Minority Rights in Historical Perspective." Review of International Studies 34 (2): 243-263.

Martyn-Hemphill, Richard. 2016. "Face Veils Are Rare in Latvia. It Still Wants to Ban Them.” New York Times, April 20.

https://www.nytimes.com/2016/04/20/world/europe/latvia-face-veils-muslimsimmigration.html 
Merrills, John G. 1993. The Development of International Law by the European Court of Human Rights. Manchester, UK: Manchester University Press.

Mullally, Siobhán. 2011. "Civic Integration, Migrant Women and the Veil: At the Limits of Rights?" Modern Law Review 74 (1): 27-56.

Narkowicz, Kasia, and Konrad Pędziwiatr. 2017. "Saving and Fearing Muslim Women in 'Post-Communist' Poland: Troubling Catholic and Secular Islamophobia.' Gender, Place and Culture: A Journal of Feminist Geography 24 (2): 288-299.

Open Society Foundations. 2011. Living Together: Projects Promoting Inclusion in 11 EU Cities. https://www.opensocietyfoundations.org/reports/living-together-projects-promotinginclusion-11-eu-cities.

Orbán, Viktor. 2018. "Speech at the Annual General Meeting of the Association of Cities with County Rights." February 11. http://www.kormany.hu/en/the-prime-minister/the-primeminister-s-speeches/prime-minister-viktor-orban-s-speech-at-the-annual-general-meeting-ofthe-association-of-cities-with-county-rights.

Pap, András L. 2018. Democratic Decline in Hungary: Law and Society in an Illiberal Democracy. London and New York: Routledge.

Peleg, Noam. 2018. "Marginalisation by the Court: The Case of Roma Children and the European Court of Human Rights.” Human Rights Law Review 18 (1): 111-131. 
Rosting, Helmer. 1923. "Protection of Minorities by the League of Nations." The American Journal of International Law 17(4): 641-660.

Schokkenbroek, Jeroen. 2006. "The System of Restrictions". In Theory and Practice of the European Convention on Human Rights, edited by Pieter van Dijk, Fried van Hoof, Arjen van Rijn, and Leo Zwaak. Antwerp: Intersentia.

Slaughter, Anne-Marie. 2000. "Judicial Globalization.” Virginia Journal of International Law 40: 1103-1124.

Vidra, Zsuzsanna. 2017. Counter-Islamophobia Kit: Dominant Islamophobic NarrativesHungary. Policy Documentation Center Working Paper No. 7. Leeds, UK: University of Leeds. http://pdc.ceu.hu/archive/00007234/.

Wodak, Ruth, and Salomi Boukala. 2015. "European Identities and the Revival of Nationalism in the European Union: A Discourse Historical Approach." Journal of Language and Politics 14 (1): 87-109.

Yourow, Howard Charles. 1996. The Margin of Appreciation Doctrine in the Dynamics of European Human Rights Jurisprudence. The Hague: Kluwer.

\footnotetext{
Notes

${ }^{1}$ The Court's jurisprudence is, for example, referred to in judgments of the Inter-American Court of Human Rights, Canadian Supreme Court, and the Constitutional Court of South Africa (see Ricardo Canese v Paraguay 2004; Alberta v Hutterian Brethren of Wilson Colony 2009; Harold Bernstein and Others v L. von Wielligh
} 
Bester NO and Others 1996, paras. 111-113). For an older discussion of the influence of the Court's jurisprudence on the Inter-American Court of Human Rights, see Merrills 1993. This cross-referencing between international and national courts, and even across regions, was first traced by Slaughter (2000), who highlighted that in the globalized legal context, courts in different jurisdictions increasingly take note of one another's jurisprudence, triggering cross-references, mutual influence, and cross-fertilization, which she coins "transnational judicial dialogue."

${ }^{2}$ A noteworthy case in which the Court opened to substantive equality is Thlimmenos v Greece (2000), in which the Court recognized that the prohibition of discrimination is "also violated when States without an objective and reasonable accommodation fail to treat differently persons whose situations are significantly different" (para 44.]).

${ }^{3}$ It is important to acknowledge that the Court's jurisprudence in relation to complaints from persons belonging to minorities about invidious discrimination has become more robust over time in the sense that it reduces the states' margin of appreciation (while the operation of the special allocation of the burden of proof remains underdeveloped). For a more detailed analysis, see Henrard 2016.

${ }^{4}$ Initially, there was no mention of the margin of appreciation in the ECHR. It was the Court that developed the doctrine. Admittedly, protocol no. 15, concluded on June 24, 2013, did (on entry into force) add a preamble to the ECHR that refers to the margin of appreciation: "Affirming that the High Contracting Parties, in accordance with the principle of subsidiarity, have the primary responsibility to secure the rights and freedoms defined in this Convention and the Protocols thereto, and that in doing so they enjoy a margin of appreciation, subject to the supervisory jurisdiction of the European Court of Human Rights established by this Convention". No further criteria were added in the preamble or text of the ECHR. Thus, it is the Court that gives substance to the margin of appreciation doctrine.

${ }^{5}$ The Committee of Ministers is now mandated to supervise compliance with ECHR judgments but its abilities to put pressure on states is limited. In other words, there is still not a mechanism that can actually force states into compliance. As noted in Europe's Human Rights Watchdog (n.d.), the Council of Europe stipulates: "Should a member state refuse to implement a judgment, the Committee of Ministers can apply multilateral peer-pressure or bilateral pressure from neighbouring states. It can also threaten the member state in question with the publication of a list, containing all its pending cases before the Court, or-as a last resort—with the exclusion from the Council of Europe. All these forms of pressure are only 'soft measures' but since they have the potential to let a member state loose face, they nevertheless hold a certain power." 
${ }^{6}$ The Court has also been willing to narrow the margin of appreciation of states regarding the regulation of religious garments in the courts when it concerns witnesses (Hamidovic v Bosnia Herzegovina 2017) or third parties (Lachiri v Belgium 2018).

${ }^{7}$ These cases are also significant in relation to the increase in integration requirements states impose on migrants, as the Court for the first time explicitly reacted to "integration" justifications by governments and adopted integration language.

${ }^{8}$ See also the critical discussion by Mullally (2011) of the Parliamentary Commission Report on the wearing of the voile integral (face veil or "integral veil") France (Gerin Report), which preceded the adoption of the act at issue in SAS v France 2014.

${ }^{9}$ In this respect, it can be noted that the applicant complained about indirect discrimination because she is a Muslim woman who for religious reasons wishes to wear the full-face veil in public and so would be particularly exposed to the ban and the sanction it provided (SAS v France 2014, para. 160). However, these indications that the act and the ban it enshrines actually target Muslim women point to a case of hidden direct discrimination. For further discussion of the complexities involved in distinguishing between direct and indirect discrimination, see Henrard 2018.

${ }^{10}$ This is reflected in the limitation clauses in human rights conventions (for example, ECHR, article 9, para. 2) and the corresponding jurisprudence of the supervisory bodies; see also the discussion of the ECtHR cases in this article.

${ }^{11}$ For an argument that supports our reading of "veiled nationalism" underlying the French act concerned, see Mullally 2011,32.

${ }^{12}$ See also the project by the Open Society Initiative for Europe, which uses living together, inclusion, and integration almost interchangeably (Open Society Foundations 2011).

${ }^{13}$ The Court's tendency to grant states a broad margin of appreciation in cases revolving around questions of national identity has been problematized in various articles, including Edmunds (2012, 1181), where she points to the limits of postnationalism; see also Augenstein (2013, 470-472), who further develops this throughout his article. We do not merely apply this reasoning to the recent cases on burqas in which the Court introduced integration language in its jurisprudence but build on this argument when claiming that the Court, when condoning this veiled nationalism, risks fueling nationalism and nationalist politics.

${ }^{14}$ For a more detailed argumentation of this criticism of the Court's jurisprudence, see Henrard 2019.

${ }^{15}$ See below for an argument that this line of reasoning implies a reversal of the human rights logic. 
${ }^{16}$ It should be noted, however, that since the SAS v France (2014) judgment, several other countries have adopted legislation that amount to burqa prohibitions. Cases with similar facts against Belgium have since come before the Court. Strikingly, the Belgian government used the same arguments as France. The Court followed the argumentation it had adopted in the French case, thus signaling the adoption of a new line of jurisprudence (Belkacemi and Oussar v Belgium [2017]; Dakir v Belgium [2017]); see also Ferri's report in Strasbourg Observers, July 25, 2017.

${ }^{17}$ When assessing the scale of the potential impact of particular judgments, it is important to keep in mind that the ramifications of such judgments and the rubber stamping of nationalist stances by governments potentially extend beyond Europe, given the status of the Court. As a highly regarded international human rights court, it is often a source of inspiration for other human rights courts and thus partakes in transnational judicial dialogue. 